Kaygl, 18(II)/2019: 514-529. Araştırma Makalesi | Research Article

Makale Geliş | Received: 24.05.2019

Makale Kabul | Accepted: 29.08.2019

Yayın Tarihi | Publication Date: 30.09.2019

DOI: $10.20981 /$ kaygi.617932

Faruk MANAV

Dr. Öğr. Üyesi | Assist. Prof. Dr. Nevşehir Hacı Bektaş Veli Üniversitesi, Fen-Edebiyat Fakültesi, Felsefe Bölümü, Nevşehir, TR Nevşehir Hacı Bektaş Veli University, Faculty of Arts and Sciences, Dep. of Philosophy, Nevşehir, TR

ORCID: 0000-0002-4588-7886

faruk-manav@hotmail.com

\title{
Miguel de Unamuno'da Varoluş ve Yaşamın Anlamı Sorunu
}

$\ddot{O} z$

Varoluşçuluğun temsilcilerinden birisi olan Unamuno, eserlerini genellikle roman ve hikâye gibi edebi tarzlarda kaleme almıştır. $\mathrm{O}$, insanın önceden belirlenmiş bir öze göre yaşamadığını savunmaktadır. Bu yüzden insanın varoluşunu ve yaşamını anlamlandırması, diğer varoluşçularda olduğu gibi Unamuno'da da önemlidir. $\mathrm{O}$, bu anlam arayışında aklın hiçbir zaman rehber olamayacağını savunmaktadır. Çünkü ona göre, yaşamı anlamlandırmanın yolu akıldan değil, yaşamı deneyimlemekten geçmektedir. Bu nedenle Unamuno felsefesi, bireysel varoluşu ve yaşamı yücelten bir anlayışa sahiptir. Ancak insanın sonlu ve ölümlü bir varlık oluşu, onu tedirgin etmektedir. Fakat insan, ölüme rağmen, yaşamayı tercih etmeli ve ona anlam vermelidir

Anahtar Kelimeler: Unamuno, Varoluş, Ölüm, Yaşam.

\section{The Problem of Existence and Meaning of Life in Miguel De Unamuno}

\begin{abstract}
Unamuno, one of the representatives of existentialism, wrote his works generally in literary sytles such as novels and stories. He argues that man does not live according to a predetermined essence. Thus man's bringing meaning to his own existence and life is important for Unamuno as it is for other existentialists. He argues that reason cannot be a guide in this search for meaning. Because according to him, meaning could be brought to life, not through reason, but only through experiencing life itself. Therefore Unamuno's philosophy has a conception that dignifies individual existence and life. However, man is disquieted by the fact that he is a finite and mortal being. But despite death, man should choose to live and give meaning to life.
\end{abstract}

Keywords: Unamuno, Existence, Death, Life. 


\section{Giriş}

Varoluşçulukta insan, önceden belirlenmemiş bir öze göre yaşamını sürdürürken, bu yaşamda yapılan seçimler ve alınan kararlar, onun ne olacağını belirlemesi, yani özünü oluşturması bağlamında düşünüldüğünde, hayati önem taşımaktadır. Çünkü Sartre'ın da dediği gibi “... insan daha önce tanımlanamaz, belirlenemez; hiçbir şey değildir o zaman. Ancak sonradan bir şey olacaktır ve kendini nasıl yaparsa öyle olacaktır." (Sartre 2007: 39). Böylece insanı kendisini belirleyen bir varlık olarak gören bir akım olarak varoluşçuluk, onu özgür seçimleri ile kendi varoluşunu anlamlandıran, bu seçimlerin sorumluluklarını alan bir varlık olarak görmektedir (Güçlü vd. 2008: 1521-1523). Varoluşçulukta ön plana çıkan bazı temalar ise varoluşun özden önce gelmesi, zamansallık, insan merkezli bir felsefe olması nedeniyle hümanizm, özgürlük ve sorumluluk ile etik düşüncelerdir (Flynn 2006: 8). Ayrıca, varoluşçulukta soyutluk yerine somutluk ön plana çıkmaktadır. $\mathrm{Bu}$ nedenle kimi filozoflar, düşüncelerini sistematik olmayan bir tarzda ve dolaylı şekilde, bazı edebi eserler vasıtasıyla göstermektedirler (Foulquie 1998: 37-40).

İspanyol düşünce dünyasının önemli filozoflarından birisi olarak görülen Unamuno da felsefesini şiir, roman ya da dinsel türdeki eserleri yoluyla sembolik bir anlatımla dile getirmekte ve bu felsefenin özünü de bireysel yaşam oluşturmaktadır (Koestenbaum 2006: 566). O, felsefesinde her türlü soyutlamaya karşı somutluğu ön plana çıkartma eğilimindedir. Çünkü insanın hiçbir soyut kavram içine hapsedilemeyeceğini savunmaktadır. O, insanın ne olduğundan ya da ne olması gerektiğinden ziyade, ne olacağını ve ne olmayı istediğine odaklanmaktadır (Mora 2003: 34-41). Düşüncesinde sergilediği bu tavırla, varoluşçuluğun temsilcileri arasında yer alan Unamuno'nun düşüncesinin bazı ana hatlarını Koestenbaum (2006: 566) şu şekilde ifade etmektedir:

Birincisi, onun felsefesi açık bir şekilde zaman ve mekân içindeki kendi insani durumundan beslenmektedir. İkincisi, yazıları düşünsellikten ziyade duygulu olma eğilimindedir. $O$, kesin fikirleri değil duyguları/hisleri ifade etmek istemektedir ve hisler sıklıkla mantıksal yorumdan daha doğru bir şekilde Unamuno'nun abartılı ve yarı-duygusal dilinde ifade edilmektedir. Üçüncüsü, onun ilgi konusu varoluşsaldır-ölüm ve kaygı, şüphe ve iman, suç ve ölümsüzlük 
gibi. Dördüncüsü, o Blaise Pascal ve Søren Kierkegaard gibi düşüncesine kaynaklık eden öncü varoluşçuların izini takip eder ve insan yaşamı ile dünya görüşünün inşasında öznelliği ve sezgiyi vurgulayan Arthur Schopenhauer, Friedrich Nietzsche ve William James gibi filozoflarla da yakınlık bulur. Son olarak, Unamuno'nun felsefesi, Kierkegaard'ınki gibi düşünüp tasarlanmış bir şekilde sistematik olmayan, onun varoluşla boğuşmasının bir ifadesidir...

Elbette varoluşçu bir filozofu sadece bahsi geçen bu maddeler arasına hapsetmek olanaklı değildir. Bu yüzden Unamuno'nun felsefesini, varoluşçuluğun tüm nitelikleri ve özellikleri ile birlikte daha geniş bir bakış açısı ile değerlendirmekte yarar bulunmaktadir.

Eserlerini çoğunlukla roman ya da hikâye tarzlarında kaleme alması ile Unamuno'nun felsefesini, bu tarz eserlerdeki karakterler aracılığıly gözler önüne serdiğini söylemek doğru olacaktır (Mora 2003: 41). Bu bakımdan çalışmada, Unamuno'nun roman ve hikâyeleri analiz edilerek onun varoluşçuluğu hakkında bir çözümleme yapılmıştır. Onun varoluşçuluğunun ana hatları ortaya konularak özellikle varoluş ve yaşamın anlamı konusundaki görüşlerini irdelemek amaçlanmıştır. Böylelikle Unamuno'nun düşüncesinde, insanın kendini anlamlandırma çabası ya da anlam arayışı tartışılmıştır. Bunu yaparken de zaman zaman diğer varoluşçu fillozoflarla ilişkilendirmeler yapılmıştır.

Unamuno felsefesi/düşüncesi hakkında ise uluslararası ve ulusal literatürde yapılmış olan bazı çalışmalar bulunmaktadır. Bu çalışmaların ulaşılabilenlerinden bazıları, Unamuno'nun onun etkilendiği filozoflardan birisi olan Søren Kierkegaard ${ }^{1}$ ile karşılaştırılmasına ya da ilişkilendirilmesine (Fasel 1955; Webber 1964; Wright 2004; Evans 2008; Ardila 2011; Evans 2013), bazıları ise Unamuno varoluşçuluğunun farklı konularına (Schlottman 1956; Mora 1961; Sobosan 1974; Marcone 1989; Franz 1999; Watson 2004; Anyadubalu 2012) odaklanmaktadır. Ulusal literatürde yapılmış çalışmalar ise genellikle dil ve edebiyat alanında yoğunlaşırken (Erteber 2008; Aksoy 2010; Gözcü Çivi 2012; Kaya Özdoğan 2015; Kayacık 2016), felsefe alanında yapılmış

\footnotetext{
${ }^{1}$ Unamuno üzerinde en büyük etkiyi bırakan filozofun Kierkegaard olduğu bilinmektedir (Fasel 1955; Webber 1964; Wright 2004).
} 
ve Unamuno’da trajik kavramının irdelendiği bir çalışmaya da (Ülgen Kaya 2012) ulaşılmıştır.

\section{Unamuno’nun Varoluşçuluğuna Kısa Bir Bakış}

Unamuno, diğer varoluşçularda olduğu gibi insanın önceden belirlenmiş bir plana göre yaşamadığını ve belirli bir çerçeve içerisine hapsedilemeyeceğini savunmaktadır. $\mathrm{O}$, insanın başka bir insan tarafından yönlendirilmesinin, bir kalıba sokulmasının, hatta Aşk ve Pedagoji'de Carrascal'ın yaptığg gibi bilimsel bir bakış açısıyla herhangi bir nesneyi inceler gibi incelenmesinin de olanaksız olduğunu göstermektedir (Unamuno, 2017a). Romanın karakteri Carrascal, öyle bir karakterdir ki, hayatta her şeyin bilimsellikle aşılabileceğini düşünmekte ve insan da dâhil olmak üzere her şeye bir nesne gözüyle bakmaktadır. Örneğin, hamile olan eşinin doğumunu istediği gibi yapamayacağını düşünerek “ 'Ah keşke biz erkekler doğursaydık,'... 'Bu işi daha bilimsel ve bilinçli bir şekilde yapardık.' " (Unamuno 2017a: 36) demesi bu düşüncesinin zirve noktasıdır. Doğacak çocuğunun dâhilik yoğunluğunu hesaplamaya çalışması, eşinin yiyeceklerinin besin değerlerini ve türlerini hesaplaması, ona vereceği ismin bilim dili olmasından dolayı Yunanca olması gerektiğini düşünmesi, çocuğun ağzından çıkan ilk anlamsız kelimenin farklı dillerdeki anlamlarını araştırarak bir anlam vermeye çalışması, oğlunun yaşamına müdahale etmeye çalışması ve hatta okula karşı1t bir tutum sergileyerek oğlunu kendisinin eğitmeye çalışması gibi davranışlar, Carrascal'ın nesnelci, akılcı ve kabul edilemez davranışlarının bazılarıdır (Unamuno, 2017a).

Oysaki insanı böylesine bir kalıba sokmaya çalışmak mümkün müdür? Nitekim Carrascal'ın oğlu Apolodoro'ya Bay Fulgencio'nun şu öğütleri aslında bu sorunun yanıtını vermektedir:

Seni kategorize etmelerine izin verme; tüylü kuyruğuyla izlerini silen tilki gibi yap; kandır onları. Onların gözünde mantık dışı ol, ta ki seni sınıflandırırken şöyle diyene kadar; bu o, Apolodoro Carrascal, türünün tek örneği. Kendin ol, ta kendin, tek ve değiştirilemez. Hareketlerinde ve sözlerinde sadece tek bir tutarl1lık prensibi olsun; bizzat kendin (Unamuno 2017a: 95). 
Öyleyse insan, akıl ile açıklanan bir varlık olmadığı gibi, onu kategorize etmek ve bir kalıba sokmak da mümkün değildir. İnsanın uğruna yaşaması gereken şey, kendisi olmaktır. Yani, biricik ve kendine özgü bir varlık yapısına sahip olmaktır. İnsan, bunu da başkalarının kontrolünde ya da onların denetiminde değil, bizzat yine kendi özgür seçimleri ile gerçekleştirmek durumundadır. Unamuno'nun da dediği gibi

Özgürlük, özgürlük, özgürlük.

Tanrı beni çağırdı: Onu dinlemeliyim. Diğerlerinin bu çağrıyı anlamamasının ne önemi var? Onların kölesi gibi mi yaşamam gerekiyor?

İnsan, diğerlerinin kendi hakkında edindiği izlenimle değil, kendi gerçekliğinde yaşamalı. Kendi zihnimizde; başkasının fikrinde değil (Unamuno 2017b: 65).

Unamuno'nun bu düşüncesi, diğer varoluşçu filozofların özellikle de Heidegger'in başkaları konusundaki düşünceleriyle örtüşmektedir. Heidegger (2000), Dasein'ın her durumda kendisi olan, kendi bireysel varoluşunu yine kendi olanaklarıyla anlamlandırmaya çalışan bir yapıda olduğunu belirtirken, başkaları ya da onlar arasında kaybolup gitme, onların seçimini kendi seçimi gibi görerek otantik olmayan bir varoluşa sahip olma, yani biricikliğini kaybetme gibi tehlikelere de dikkat çekmektedir. O halde insan, hem kendisini kendi özgür seçimleriyle belirleyecek hem de başkalarıyla olan ilişkilerine azami dikkati gösterecektir.

Unamuno, kişinin kendi olmasına ve bir bakıma kendi varoluşunun peşine düşmesine ilişkin düşüncesini şöyle belirtir; "Başkası olmayı istemek, olduğun kişi olmayı bırakmayı istemektir. Kişinin başkasının malı veya bilgisine sahip olmasını istemesini anlıyorum, fakat başkası olmak, bunu anlayamıyorum.” (Unamuno 2017c: 25). Başkası gibi olmayı istemeyi ya da başkası gibi davranmayı varoluşun/yaşamın anlamlandırılmasının önünde bir bakıma bir engel olarak gören Unamuno, kendi olmayı sıklıkla dile getirdiği ifadelerle de yüceltmektedir. Bu nedenle de varoluş ve yaşamın anlamı meselesinin onun düşüncesinin merkezi konularının başında geldiği de düşünülebilir. Onun şu ifadesi de bu savı destekler niteliktedir: “...bana göre başkası olmak, hayatımın birlik ve sürekliliğini bozmak, olduğum olanı, yani kısacası var olmayı bırakmak demek. Bu olmaz: Her şey olur da bu olmaz!” (Unamuno 2017c: 27). O halde, yaşamı anlamlı hale getirmenin yolu, kendi olmaktan geçmektedir denilebilir. 


\section{Unamuno'da Yaşamın Anlamı ve Kendisi Olmak}

Kendisi olmak ve kendine özgü bir varoluşa sahip olma söz konusu olduğunda, Unamuno'nun eserlerinde ön plana çıkan bazı konular vardır ki, bu konular, varoluşun zorlu yollarının, kendine özgü bir birey olarak yüklenilmesinin ne denli ağır olduğunu gösterir niteliktedir. O demektedir ki, "Eğer bir gün var olmayı bırakmak acı veriyorsa, hep kendin olmayı sürdürmek, aynı zamanda başkası olamadan yalnızca kendin olmak, aynı zamanda başkaları olamamak, herkes olamamak belki daha çok acı verir." (Unamuno 2017c: 157). Kişinin kendisi olması, özgün bir yaşama ve varoluşa sahip olması acı vericidir. Ancak bazen bu zorlu yol yerine, bu yoldan kaçış sergilenebilmektedir. $\mathrm{Bu}$ da kişinin kendisini sıradanlığga kaptırması ya da kendisi olmaktan kaçması anlamını taşımaktadır. Unamuno'nun dile getirdiği bu durum, Kierkegaardçı bir ifadeyle söylenecek olursa hazza dayalı, kişinin kendisi olmaktan kaçtığı ve özgür olmayış arzusuyla belirginleşen estetik varoluşa (Michelman 2008: 202), Heideggerci bir ifadeyle söylenecek olursa Dasein'ın kendisini olanakları yerine gündelik yaşamın sıradanlığına kaptırdığg otantik olmayan bir varoluşa (Heidegger 2000) karşılık gelmektedir.

Söz gelimi Unamuno'nun Bonifacio adlı hikâyesinin kahramanı Bonifacio, yaşamı genel olarak sıkıcı ve anlamsız bulan bir karakterdir. $\mathrm{Bu}$ nedenle de kendini sahte bir arayışla kandırmakta ve bir bakıma yaşamı anlamlı hale getirmek için hiçbir şey yapmamakta ve sıradan bir yaşamı tercih etmektedir. Hatta aşkı bile gereksiz görmektedir (Unamuno, 2016a). Böylelikle Bonifacio, aslında yaşamın zorlu yollarından kaçan, bağlanmayı yaşamının herhangi bir safhasında gerekli görmeyen, hatta ne yapacağını ve ne olacağını bile bilmeyen bir tür estet karakter olarak görülebilir. Unamuno onun için şöyle der; "Bonifacio karamsar değildi. Bonifacio iyimser de değildi, Bonifacio hiçbir şey değildi, hiçbir şey olmak istemiyordu, isteyip istemediğini bile bilmiyordu. Zavallı Bonifacio!” (Unamuno 2016a: 56). Böylesi istikrarsız bir yaşamda, yaşamını anlamlandırmaktan uzak olan kişinin özgür şekilde seçimler yapması, kararlar alması ve bu kararların sorumluluklarını üstelenmesi de pek olanaklı değildir. Unamuno (2016b), bu durumu İki Anne adlı hikâyesinde gösterir. 
Hikâyenin kahramanı Don Juan, evli olduğu Raquel'den çocuk sahibi olamayınca, Raquel onu başka bir kadınla evlenerek çocuk sahibi olmaya zorlar. Bu zorlama sonucunda da Berta'dan çocuğu dünyaya gelir ancak her iki kadına da eş olamadan yaşamını yitirir. Hikâyede Don Juan'ın yaşadığı durum, eşiyle yaşamına devam etmek ya da başka bir kadından çocuk sahibi olarak sürüncemede bir yaşam sürmek şeklinde ortaya çıkan, iki seçenek arasında yaşadığı gerilim ve ikilem durumudur. Ancak, Don Juan'ın kendi kararını verememesi onun özgürlüğünü de sorunlu bir hale sokmaktadır. Yani, aslında özgür olmadan alınan kararlar tartışılır nitelikte olup her durumda pişmanlık yaratma potansiyeli taşımaktadır. (Unamuno, 2016b). Tıpkı Kierkegaard'ın estetik varoluş alanındaki kişi için söylediği gibi;

Evlenirsen, pişman olursun; evlenmezsen, yine pişman olursun; evlen ya da evlenme, pişman olursun; ister evlen, ister evlenme pişman olursun. Dünyanın aptallıklarına gül geç, pişman olursun; gözyaşı dök, yine pişman olursun; dünyanın aptallıklarına gül geç ya da gözyaşı dök, pişman olursun; dünyanın aptallıklarına ister gül geç ister gözyaşı dök, pişman olursun. Bir kadına inan, pişman olursun; inanma, yine pişman olursun; bir kadına inan ya da inanma pişman olursun; bir kadına ister inan ister inanma, pişman olursun (Kierkegaard 2005: 73).

Kendi olmaktan uzak bir yaşamı tercih eden kişinin belirli bir kişiye bağlanmaktan kaçan ve aşk konusunda da başarısızlığa uğrayan bir özellik sergilediğini de sıklıkla gündeme getiren Unamuno, böyle bir karakterin belirli bir kadında aşkı bulamayacağını ve onun istikrarsız aşk hayatının mutlu bir sonla bitmeyeceğini de gözler önüne serer. Özellikle Sis (Unamuno, 2017d) romanında çizilen karakter profili, bunu en iyi şekilde örneklendirmektedir. Romanın başkarakteri Augusto Perez, farklı kadınlarda gördüğü farklı özelliklere âşık olan ve kadınları beğenme konusunda kendisine bir sınır da koyamayan bir karakterdir. Augusto'nun şu ifadesi onun aşka, bir bakıma bağlanmaya bakışını göstermektedir. "Evden çıkalı yarım saat oldu olmadı; üçüne, yok hayır, dördüne birden âşık oldum. Önce, yalnız gözden ibaret sanki, öyle birine; sonra saçları şahane bir ikincisine; işte demin de canlı melekler gibi gülümseyen biri esmer, biri kumral bir çifte. Dördünün de peşine düştüm.” (Unamuno 2017d: 75). Birden fazla kadına âşık olduğunu sanmak, istikrarsız bir yaşamı ve aslında ne olacağını seçememeyi de göstermektedir denilebilir. Çünkü kişi eğer bir kişiye bağlanırsa bu 
onun artık kendisine nişan ve evlilik gibi bir sorumluluk yüklemesi ve daha etik olan bir yaşamı tercih etmesi anlamına gelecektir. Oysa Augusto, tercihini hep istikrarsızlıktan yana kullanmaktadır. Hatta bu tercihine bahaneler bile bulma peşindedir: "Eugenia beni soyuttan somuta götürdü; Rosario ise bana, insan soyunun genel niteliklerini öğretti. İnsanın imreneceği öyle çok kadın var ki... Nice nice Eugenia nice nice Rosario var! Hayır, hayır kimse oynayamaz benimle; hele kadınlar hiç! Ben benim. Ruhum küçük belki; ama benim sahibi!" (Unamuno 2017d: 133). Augusto, her ne kadar böyle bahanelere sığınsa da kendine bu konuda sınır koyamaması ve aynı yaşam tarzına devam etmesi, onu hiçbir şekilde gerçek (otantik) bir varoluşa yaklaştırmayacaktır. Nitekim "Hayalime, kafama hitap eden Eugenia başta; sonra kalbime hitap eden Rosario; nihayet bir de mideme hitap eden ahçım Ludivina. Kafa, kalp ve mide; başkalarının akı1, his ve irade adını taktıkları üç ruhi melekedir. İnsan kafasıyla düşünür, kalbiyle duyar, midesiyle ister. Açık, belli bir şey bu!” (Unamuno 2017d: 169), diyerek sonu olmayan arzuların ve kendinden kaçışların onu hiçbir şekilde anlamlı bir yaşama yaklaştırmayacağını da bir bakıma perçinlemiş olmaktadır.

Unamuno benzer şekilde Aşk ve Pedagoji'de de tek bir kadına bağlanmaktan kaçan ve birden fazla kadını düşleyen bir karakter üzerinden aslında estetik ya da otantik olmayan bir varoluşun istikrarsızlığını, anlık duyusal zevklere dönüklüğünü göstermek ister. Romanın karakteri Avito Carrascal, birden fazla kadını tek kadın haline getirmenin düşünü kurmaktadır. Unamuno Carrascal'1 şöyle tasvir eder: "Şimdi Marina'ya sahipken Leoncia'yı daha çok düşünmektedir, kara-kuru kızın saçlarını koklarken, uzun sarışının saçlarını hayal eder. İkisini tek yapmak keşke mümkün olsaydı!..” (Unamuno 2017a: 31). O halde, kişinin sürdüreceği böyle bir yaşam, anlamlı olmak bir yana, sonu genellikle hüsran ile biten ve varoluşçu anlamda istenen bir yaşam da olmayacaktır.

Her insan kendi yaşamını kendisi yaşar. Çünkü yaşamı sadece insanın kendisi deneyimleyebilir ve yaşam başkasından öğrenilemez. Sis'te Don Avito der ki, "Hayatın tek mürşidi hayattır; hiçbir pedagoji ona erişemez. İnsan, yaşamayı yaşayarak öğrenir ve herkesin, daima yeni baştan yaşamayı öğrenmeye başlaması gerekir." (Unamuno 2017d: 
92). Bu da şu anlama gelmektedir ki, yaşayarak yaşamayı öğrenen insanın yaşamdan kaçışı olanaksızdır. Yani insan, bir kez bu dünyada var olduktan sonra yaşamın zorlu yollarına adım atmış demektir. Unamuno, yaşamdan kaçmanın olanaksızlığını Sessizlik Mă̆arası adlı hikâyesinde şöyle dile getirir: "Ne çare ki bu tedbir daima, sonunda şeytana uyduğu için, nöbetçinin uçurumda kaybolmasıyla neticeleniyor, nöbetçilerle birlikte mağaradan içeri girilmesine mâni olmak isteyen başkaları da hep birden ortadan silinip gidiyorlard1." (Unamuno 2016c: 136). Hikâyede yer alan bu mağara benzetmesinin, aslında yaşamı sembolize ettiği düşünülebilir. Hikâyede mağaraya giren her insanın çıkamaması, yaşama adım atan her insanın var olmaktan kaçamamasına, yaşamı yaşamak durumunda olan insanın, sorumluluktan ya da sorumlu olmaktan kaçamayacağına karşılık gelmektedir denilebilir. Bu nedenle, mağaranın başına nöbetçi dikmek bile yaşamdan kaçmaya engel olamamaktadır. Çünkü insan, bir kez dünyaya geldi mi, yaşamak durumundadır. Yaşamın anlamını aramak, yani mağaraya girmek yerine, intihar ederek kurtulma çabası gösterenler de aslında yaşama sorumluluğunu göze alamayanları sembolize etmektedir (Unamuno 2016c).

Yani bu dünya içinde oluş ve var olma çabası, yaşamın yükünü sırtlanmayı gerektiren zor bir süreçtir ve kaçış olanaksızdır. Bu nedenle de yaşama anlam yüklemek, yaşamdan kaçarak değil, bizzat yaşamı yaşayarak gerçekleşmektedir. Ancak bu yaşam, Unamuno'ya göre oldukça zorlu yolları olan ve saçmayı da içinde barındıran bir yaşamdır. O, Sis’te yaşam için şu betimlemeyi yapar; “...Tanrım! Ne büyük acılar ne de büyük sevinçler öldürür insanları; bu yüzden bu acı ve sevinçler, küçük küçük değersiz şeylerden oluşmuş muazzam bir sisle sarılı gözükürler. Evet, işte hayat dediğin; bir sis olup olacağı! Hayat bir sistir.” (Unamuno 2017d: 30). Yaşamda hiçbir şey berrak, net ve tozpembe değildir. Yaşam yolu, bazen inişli bazen çıkışlı bazen de sisli bir yol gibi muğlaktır. Böylesine bir yaşam ise başlangıçta tüm insanlara anlamsız ve boş gelme potansiyeli de taşımaktadır. Unamuno Aşkın Hücumu adlı hikâyesinde bu durum için şöyle der: “Anastasio'nun duygusuna göre hayattan daha boş, daha sıkıntılı, daha manasız, daha saçma bir şey olamazd1...” (Unamuno 2016d: 125). Çünkü Anastasio, yaşamın anlamsızlığı ve saçmalığı karşısında gerçek aşkı arayan ve inanmadığı bu aşkı, 
Eleuteria'da bulduğunu sanan karakterdir. Her iki karakter de bir bakıma gerçek aşkın ya da idealize edilmiş aşkın yaşama anlam katmadığını göstermektedir. Hikâyenin mutlu bir son ile değil, ölüm ile sonuçlanması bu düşünceyi güçlendirmektedir (Unamuno 2016d). Dolayısıyla aşkın, hayatın anlamsızlığına çözüm olmadığını söylemek mümkündür. Unamuno'nun eserlerinde genellikle aşkın içinde yaşadığımız dünyaya bir anlam verip vermemesi bir yana, ölüm ile sonlanması da bu çözümsüzlüğü göstermektedir denilebilir. Hatta aşk, insan için bir kandırmaca olarak da görülebilir: "Dünyadaki ve hayattaki en trajik şey aşktır, okur kardeşlerim; aşk, aldanmanın oğlu, hayal kırıklığının babasıdır; aşk, perişanlıkta tesellidir; ölümün kardeşi olan aşk, ölüme karşı devadır.” (Unamuno 2017c: 151).

Söz gelimi, Ramon Nonnato adlı hikâyede, babasının tahakkümü altında ezilen ve onun kararlarını uygulamak zorunda kalan Nonnato, hayatının hiçbir döneminde kendisi gibi olamamış, kendi kararlarını alamamış, kendisi gibi yaşayamamıştır. O, başkası, yani babası için var olduğundan, bu yaşam tarzı onu bir bakıma zor ve çekilmez bir yaşama sürüklemiştir. Sonunda intihar yolunu seçerek yaşamını sonlandırmıştır (Unamuno 2016e). Sis’te de Augusto, yaşamın saçmalı̆̆ karşısında ya da yaşamdan istediklerini elde edemediğini düşündüğünde intihar yolunu seçmekte ve nitekim çok aşırı yemek yemekten dolayı ölmektedir (Unamuno 2017d: 204). Buradan anlaşılan şudur ki, yaşamın anlamsızlığı, saçmalığı ve her zaman kişiye istediğini vermemesi, yaşamı sonlandırarak ya da intihar yolunu seçerek aşılacak bir şey değildir. Yaşam, kişinin kendi deneyimleriyle anlam kazanacağından dünya içindeki her türlü deneyimin aslında yaşamın anlamı üzerinde belirli bir etki oluşturduğunu göz önüne almak belki de iyi bir çözüm olacaktır. Aynı şekilde Camus'de olduğu gibi "İntihar bundan ötürü, absürde'e başkaldırdığımızı ya da özgür olduğumuzu göstermez, aksine absürde'e boyun eğdiğimizi gösterir. Öyleyse absürde'e boyun eğmemek için hayatı yaşamak zorundayı.” (Gündoğan 1995: 87). 


\section{Ölüm ve Yaşam}

Yaşamın anlamı söz konusu olduğunda Unamuno'nun gündeme getirdiği bir başka olgu daha vardır ki, o da ölümdür. Yani ölüm basit bir son mudur? Yoksa yaşamın ve varoluşun anlamlandırılması konusunda vazgeçilmez bir unsur mudur? Unamuno, ölümün yaşamı anlamlandırması konusunda da diğer varoluşçu filozoflardaki gibi bir tutum (Bollnow 2004: 77-79) izlemektedir. Ölüm, aslında basit bir son değil, aksine yaşamın akışına yön veren varoluşsal bir olgudur. $\mathrm{O}$, ölümün yaşamla ilişkisini şöyle dile getirir: "Ölüm yaşamın doğal sonu olduğuna göre, yaşamın doğal yolu da ölüme doğru gitmektir, yaşamın doğal ışığı ise kendi sonunda görünen ışıktır. Yaşam ancak ölümün 1şı̆̆ında anlaşılır. Ölmeye hazırlanmak doğal şekilde yaşamaktır.” (Unamuno 2017b: 18). Yani ona göre ölüm de yaşamın bir parçası ve her ölüm bireysel ölüm olarak anlaşılmak durumunda olduğundan, bireysel olarak son derece önemli bir konuma sahip olmaktadır. Çünkü "Tanıklar son dakikada ne olduğunu bilmiyorlar ve bu son dakika biricik olduğu ve hiç kimse bunu anlatmak için geri dönmediğine göre, hiçbir şey bilmiyoruz. Deneyimi olmayan biricik şey. Sadece bir kez ölünür. Peki, bu biricik eylem için yaşamaya değmez mi? Ölmek için yaşamaya?" (Unamuno 2017b: 51). O halde ölüm, kişiye özgü olan ve sadece kişinin deneyimleyebileceği, yaşamı anlamlandıran bir olanaktır.

Unamuno'nun bu düşüncesi, bir başka varoluşçu filozof Heidegger'in Dasein'ın ölümü konusundaki düşüncelerini anımsatmaktadır. Heidegger'e göre, basit bir son olmayan ölüm, bizzat yaşamın içinde yer alan ve ona olumlu anlamda etki eden, bir bakıma ona sınırlarını fark ettiren, Dasein'ın başkasına devredilemez olanağı olarak, sadece onun gerçekleştirebileceği ve onu aynı zamanda olanaklarından alıkoyan bir tür dünya-içinde olmama durumudur (Heidegger 2000: 284-296). Unamuno için de ölüm, insanı her şeyden alıkoymaktadır. "Hayır, bir kez öldün mü, senin için fani dünyadaki hiçbir şey artık var olmayacak!” (Unamuno 2017b: 90). İnsanı var olmaktan koparan ölüme karşı insanın takınacağı tavır ise onun farkında olarak yaşamını sürdürmekten başka bir tavır olmayacaktır. İnsan, ölümün her an gelebileceği bilinciyle yaşamını anlamlandırmanın yolunu bulmak durumundadır. Çünkü bir kez ölünüyor ise bu aynı 
zamanda bir kez yaşandığı anlamına da gelmektedir. "Evet, yaşamak gerek ama ölmek de gerek. Özellikle de yaşayarak ölebilmek için ölerek yaşamak gerek... İnsan ölümle ilgili ne kadar çok düşünürse, hayat için o kadar huzurlu bir sükunete kavuşuyor. Ölümde yaşamak: Hayata ve ebedi hayata ölmenin yegâne yolu bu.” (Unamuno 2017b: 68-69). Bir kez yaşayıp bir kez ölecek olan insanın bu iki durum arasındaki dengeyi kurmasının, yani yaşamını anlamlandırmasının yolu, ölümü yaşamın içinde görmekten geçmektedir. Unamuno'nun da dediği gibi “Bir karar vermek veya önemli bir şey yapmak üzereyken, önereceğin şey olur olmaz öleceğini hayal et ve yapacağın her şeyi, hemen o an ölecekmişsin gibi yap.” (Unamuno 2017b: 122). Unamuno'ya benzer şekilde Camus de insanı yaşama bağlayan bir gerçeklik olarak ölümün insan yaşamını anlamlandırdığını ve hatta ölümle yaşamın bu bağlamda düşünüldüğünde, aynı öneme sahip olduğunu belirtmektedir (Gündoğan 1995: 100-102). Çünkü "İnsanın başlıca sorgulayışı, yaşamın bir anlamı olup olmadığına ilişkindir ve başlıca ihtiyacı da, yaşama (en azından kendi yaşamına) bir anlam verebilmektir.” (Ülgen Kaya 2012: 94). Bu nedenle yaşam, ölüme rağmen anlamlandırılmalıdır.

Yaşamın bir gün sonlanacak olması ve kişinin bunun farkına varmasıyla birlikte derin bir 1stırabın da kendini iyiden iyiye hissettireceğini belirten Unamuno, yaşamanın bu trajik tarafının da aslında kişiyi yaşamaktan alıkoymaması gerektiğini belirtir. Hatta yaşam bir rüyadan ibaret olsa bile yaşamaya değeceğini dile getirir (Unamuno 2017c: 63-65). İnsanın ölümü fark etmesine karşın, ölmeyi istememesine ölümsüzlük adını veren Unamuno, insanın yaşamı boyunca ölümden kaçmasının, kendini yaşamına adamasının temelinde de bu arzuyu görmektedir (Unamuno 2017c). Yani Unamuno' da insanın ebedileşmesinin yollarından biri de kendisini yapıp ettiklerine adamasından geçmektedir denilebilir. Böylelikle insan aslında kendisinden sonrakiler için bıraktıkları ile ölümsüz $z^{2}$ olabilme arzusunda olmaktadır (Ülgen Kaya 2012). Unamuno, bu arzuyu şöyle dile getirir "Her şey olmaya niyetlenmemiz, her şey olmanın hiç olmayı önlemenin tek çaresi olduğunu düşündüğümüz içindir." (Unamuno 2017c: 74). O halde,

\footnotetext{
${ }^{2}$ Unamuno felsefesinde ölümsüzlük, daha kapsamlı bir şekilde değerlendirilmesi gereken bir konu olarak düşünüldüğünden bu çalışmada, çalışmanın problemini dağıtmamak adına kısaca değinilmiştir.
} 
ölümün doğurduğu tedirginliği ve yaşamın bir gün sonlanacak olmasının ortaya çıkardığı trajik durumu ortadan kaldırmanın ya da en azından onunla mücadele etmenin yolu, bir tür ebedileşme arzusuyla beliren yaşamsal edimlerden geçmektedir.

\section{Sonuç}

Varoluşçu felsefenin temsilcilerinden birisi olarak bilinen Unamuno'nun felsefesinde insanın varoluşunu anlamlandırması ya da bir başka deyişle yaşamını anlamlı bir hale getirmesi, oldukça sancılı, zorlu ve bunalımlı bir yol olarak dikkat çekmektedir. Unamuno, akılcı davranmanın ve nesnelci bir bakış açısına sahip olmanın bu yolda işe yaramayacağını eserlerindeki karakterlerin hüsranla biten yaşamları ile gösterir. Çünkü ona göre, bir sis misali puslu, belirsiz ve trajik olan yaşam, akılcı bir bakışla değil ancak yaşayarak anlamlı hale getirilebilir. Yani Unamuno'da yaşamın anlamı, aslında insanın kendi özgür seçimleri ve kararlarıyla kısacası, kendi deneyimleri ile elde edilebilir. Ancak tabi ki, yaşamın bir gün sonlanacak olması, insanın en önemli varoluşsal durumlarından birisi olan ölümle yüz yüze gelmesine ve ölüm karşısında duyduğu tedirginlik ve 1stırap gibi duygularla baş başa kalmasına yol açmaktadır. Öyleyse yaşamın bir gün sona ereceğinin ve onu her şeyden koparacağının farkına varan insanın, yaşamını sonlandırmak yerine, yaşamını olabildiğince anlamı hale getirmeye çabalaması da önemli hale gelmektedir. Çünkü ölüm de aslında yaşamın anlamlı hale gelmesinde rol oynayan bir olanak ya da yaşamsal durum olarak nitelendirilebilir. 


\section{KAYNAKÇA}

ANYADUBALU, Christopher C. (2012). "Human Existential Desire for Immortality in Unamuno's Perspective", Global Journal of Human Social Science Arts \& Humanities. 12 (14), 52-60.

ARDILA, J. A. G. (2011). “The Origin of Unamuno's Mist: Unamuno's Copy of Kierkegaard's Diary of the Seducer”, Modern Philology, 109, (1), (August 2011), 135143.

AKSOY, Pelin (2010). Unamuno Tiyatrosunda Ölümsüzlük Teması, (Yayımlanmamış Yüksek Lisans Tezi), Ankara Üniversitesi Sosyal Bilimler Enstitüsü, Ankara.

BOLLNOW. Otto Friedrich (2004). Varoluş Felsefesi, der. ve çev. Medeni Beyaztaş, İstanbul: Efkâr Yayınları.

ERTEBER, Çağlar (2008). "Miguel de Unamuno'nun "Sfenks"' ve “Günlükler' Adlı Yapitlarındaki Benzer Kavramlar”, Littera Edebiyat Yazıları, 23, 93-100.

EVANS, Jan E. (2008). "Miguel de Unamuno's Reception and Use of the Kierkegaardian Claim That "Truth Is Subjectivity"', Revista Portuguesa de Filosofia, 64, (2/4), Horizontes Existenciários da Filosofia / Søren Kierkegaard and Philosophy Today (Apr. - Dec., 2008), 1113-1126.

EVANS, Jan E. (2013). “Unamuno's Faith and Kierkegaard's Religiousness A: Making Sense of the Struggle", Hispanófila. (168), 55-67.

FASEL, Oscar A. (1955). "Observations on Unamuno and Kierkegaard", Hispania. 38, (4) (Dec., 1955), 443-450.

FLYNN, Thomas R. (2006). Existentialism A Very Short Introduction, First Published, Oxford: Oxford University Press.

FOULQUIE, Paul (1998). Varoluşçunun Varoluşu, çev. Yakup Şahan, İstanbul: Toplumsal Dönüşüm Yayınları.

FRANZ, Thomas R. (1999). “Augusto's Mysterious Travel Plans in Unamuno's "Niebla"”, Hispanic Journal, 20, (1), (Spring, 1999), 81-95.

GÖZCÜ Çİİ, Şükran (2012). Miguel De Unamuno'nun "La Esfinge” Adlı Eserinde Varoluşçuluk, (Yayımlanmamış Yüksek Lisans Tezi), Ankara Üniversitesi Sosyal Bilimler Enstitüsü, Ankara.

GÜÇLÜ, Abdülbaki; UZUN, Erkan; UZUN, Serkan ve YOLSAL, Ümit Hüsrev (2008). Felsefe Sözlüğ̈̈, Üçüncü Basım, Ankara: Bilim ve Sanat Yayınları.

GÜNDOĞAN, Ali Osman (1995). Albert Camus ve Başkaldırma Felsefesi, Erzurum: Birey Yayıncilık.

HEIDEGGER, Martin (2000). Being and Time, trans. John Macquarrie \& Edward Robinson, Oxford: Blackwell Publishers. 
KAYA ÖZDOĞAN, Gökçe Çiçek (2015). Antonio Buero Vallejo'nun "Yakıcı Karanlıkta" Adlı Eserinde Kullandığı Motifler ve Miguel De Unamuno'nun Eserdeki Yansımaları, (Yayımlanmamış Yüksek Lisans Tezi), Ankara Üniversitesi, Sosyal Bilimler Enstitüsü, Ankara.

KAYACIK, Zeynep (2016). Miguel De Unamuno'nun Sis'i ile Sabahattin Ali'nin Kür Mantolu Madonna Adlı Yapıtlarında Varoluşsal Bir Biçim Olarak Aşk Kavramı, (Yayımlanmamış Yüksek Lisans Tezi), Ankara Üniversitesi, Sosyal Bilimler Enstitüsü, Ankara.

KIERKEGAARD, Sören (2005). Kahkaha Benden Yana, çev. Serdar Rifat Kırkoğlu, İstanbul: Ayrıntı Yayınları.

KOESTENBAUM, Peter (2006). "Miguel De Unamuno Y Jugo", Encyclopedia of Philosophy, Volume: 9, ed. Donald M. Borchert, pp. 565-569. USA: Thomson Gale.

MARCONE, Rose Marie (1989). "The Role Of Augusto Perez: A Study of "Niebla"”, Confluencia, 5, (1), (Fall 1989), 11-15.

MICHELMAN, Stephen (2008). Historical Dictionary of Existentialism, USA: Scarecrow Press.

MORA, Jose Ferrater (1961). “On Miguel de Unamuno's Idea of Reality”, Philosophy and Phenomenological Research. 21, (4), (Jun., 1961), 514-520.

MORA, Jose Ferrater (2003). Three Spanish Philosophers-Unamuno, Ortega, Ferrater Mora (Edited and with an introduction by J. M. Terricabras), Albany: State University of New York Press. Yayınları.

SARTRE, Jean-Paul (2007). Varoluşçuluk, çev. Asım Bezirci, İstanbul: Say

SCHLOTTMAN, William Harry (1956). The Problem of Immortality in the Philosophy of Unamuno, (Master Thesis), The Rice Institute, Houston, Texas.

SOBOSAN, Jeffrey G. (1974). "Passion and Faith: A Study of Unamuno", Religious Studies, 10, (2), (Jun., 1974), 141-152.

UNAMUNO, Miguel De (2016a). "Bonifacio", çev. Mesut Özden Gözütok, Ölümün Aynast, yaz. Miguel de Unamuno, çev. Mesut Özden Gözütok, ss. 53-56, İstanbul: 1984 Yayınevi.

UNAMUNO, Miguel De (2016b). "İki Anne”, çev. Yıldız Ersoy Canpolat, $\ddot{U}_{c ̧}$ Örnek Öykü ve Bir Önsöz, yaz. Miguel de Unamuno, çev. Yıldız Ersoy Canpolat, ss. 1352. İstanbul: Türkiye İş Bankası Kültür Yayınları.

UNAMUNO, Miguel De (2016c). "Sessizlik Mağarası”, çev. Behçet Necatigil, Yaman Adam, yaz. Miguel de Unamuno, çev. Behçet Necatigil, ss. 133-149. İstanbul: Can Yayınları. 
UNAMUNO, Miguel De (2016d). “Aşkın Hücumu”, çev. Behçet Necatigil, Yaman Adam, yaz. Miguel de Unamuno, çev. Behçet Necatigil, ss. 125-131. İstanbul: Can Yayınları.

UNAMUNO, Miguel De (2016e). "Ramon Nonnato (İntihar)", çev. Mesut Özden Gözütok, Ölümün Aynası, yaz. Miguel de Unamuno, çev. Mesut Özden Gözütok, ss. 23-27. İstanbul: 1984 Yayınevi.

UNAMUNO, Miguel De (2017a). Aşk ve Pedagoji, çev. Mesut Özden Gözütok, İstanbul: 1984 Yayınevi.

UNAMUNO, Miguel De (2017b). Günlükler, çev. A. Burak Zeybek, İstanbul: Sel Yayıncılık.

UNAMUNO, Miguel De (2017c). Hayatın Trajik Duygusu, çev. Mehmet Sait Şener, İstanbul: Divan Kitap. Yayınları.

UNAMUNO, Miguel De (2017d). Sis, çev. Behçet Necatigil, İstanbul: Can

ÜLGEN KAYA, Eda (2012). Unamuno ve Scheler'de Trajik Kavram1, (Yayımlanmamış Doktora Tezi), Maltepe Üniversitesi, Sosyal Bilimler Enstitüsü, İstanbul.

WATSON, Peggy W. (2004). "The Author as Privileged Authority in Unamuno's "Don Sandalio"” Hispania, 87, (1), (Mar., 2004), 42-52.

WEBBER, Ruth House (1964). "Kierkegaard and the Elaboration of Unamuno's Niebla", Hispanic Review. 32, (2), (Apr., 1964), 118-134.

WRIGHT, Sarah (2004). "Ethical Seductions: A Comparative Reading of Unamuno's "El hermano Juan" and Kierkegaard's "Either/Or"', Anales de la Literatura Española Contemporánea. 29, (2), Drama/Theater (2004), 489-504. 